\title{
Correlation Studies in Segregating Population of Brinjal (Solanum melongena L.) Developed Through Bi-Parental Mating Using Bacterial Wilt Resistant Varieties
}

\author{
Aanchal Chauhan ${ }^{1 *}$, K.S. Chandel ${ }^{2}$ and Shiv Pratap ${ }^{1}$ \\ ${ }^{1}$ College of horticulture and Forestry, Vill. - Neri, P.O. - Khaggal, Teh and Dist. - Hamirpur, \\ Himachal Pradesh-177001, India \\ ${ }^{2}$ CSKHPKV, Palampur, Dist. - Kangra, Himachal Pradesh, India \\ *Corresponding author
}

\section{A B S T R A C T}

Keywords

Correlation coefficient

(r), Character

association, Path

analysis, Bi-parental

mating, Plant height,

$\mathrm{pH}$, Fruit diameter,

$\mathrm{FD}$, Marketable yield per plant, MYPP.

Article Info

Accepted:

19 June 2017

Available Online:

10 August 2017
The present study was undertaken with the objective to determine the nature and magnitude of association between yield and it's component characters and their direct, indirect effects on marketable fruit yield per plant in brinjal (Solanum melongena L.). Forty eight bi-parental and $60 \mathrm{~F}_{3}$ progenies were evaluated for identifying their efficiency with respect to 16 yield and quality traits. The correlation studies revealed strong positive association of marketable fruit yield with fruits per plant, plant height and fruit weight. Genotypic correlations in general were high as compared to their phenotypic correlations indicated strong inherent association between the characters. The result of path analysis indicated that the fruit weight had maximum direct effect on marketable fruit yield followed by number of fruits per plant and fruit length.

\section{Introduction}

Brinjal (Solanum melongena L.) is a popular vegetable of India. It belongs to family Solanaceae and have chromosome number $2 \mathrm{n}=2 \mathrm{x}=24$ (Hazra et al., 2011). Being rich in fiber, potassium, vitamin B-6 and phytonutrients like flavonoids, this vegetable lowers the risk of heart disease. As brinjals are low in carbohydrates and high in fibre content, they are known to be good for people suffering from diabetes. Brinjal contains potassium, an important mineral, which plays a key role in maintaining electrolyte balance in the body.
It also helps in neutralizing the effects of sodium on the body thereby aiding in blood pressure control. Brinjals is rich in chlorogenic acid that acts as a powerful antioxidant agent, lowering cholesterol levels in the body, several varieties of aubergines grown all around the world. They vary widely in size, shape, and color depending upon the cultivar type. Aubergines fall into two broad categories, either oval shaped, or thin and elongated. It is grown commercially as fresh market crop especially in low and mid hill areas of Himachal Pradesh. 
The correlation between different characters is an important tool in the hands of plant breeder for making the crop improvement, whereas the path coefficient analysis partitions the correlation coefficients into direct and indirect effects. The description of the technique of path coefficient analysis for partitioning the correlation coefficient into direct and indirect effects was first published by Wright (1921). This method was further illustrated as a means of analyzing correlation coefficients by Dewey and $\mathrm{Lu}$ (1959). Johanson et al., (1955) stated that the estimates of genotypic and phenotypic correlation among the characters are useful in planning and evaluating breeding programme. The genetic improvement of a dependent trait can be achieved by applying strong selection to characters which are genetically correlated with dependent character. Sometime a character has low heritability. Under such situation, another character having high heritability and high correlation with former traits chosen to make selection more effective. Thus genetic improvement is achieved using indirect selection through component characters with high heritability.

A positive correlation between desirable characters is favourable to the plant breeder because it helps in simultaneous improvement of both the characters. In plant breeding, phenotypic and genotypic paths are commonly estimated to determine yield contributing characters. Knowledge of yield components is useful for plant breeders in selection of elite genotype from diverse genetic populations. It is quite possible that a trait showing positive direct effect on yield may have a negative indirect effect via other component traits. Path analysis permits the examination of direct effects of various characters on yield as well as their indirect effects via other component characters. Thus through the estimates of direct and indirect effects, it determines the yield components.
Adams and Grafius (1971) have mentioned that yield should be considered as end product of a number of traits and breeder should not ignore the principle of balance among these traits. So, it is beneficial to know the association of various economically important traits. This consideration becomes more useful when one visualizes yield as a complex trait and product of the interaction of several traits. Correlation studies between characters also play an important role in the determination of the most efficient breeding procedures. Stronger the association of a trait with yield, the more will be the success of a selection programme. Therefore this investigation was undertaken with the objective to determine the nature and magnitude of association among different traits and their association with fruit yield in segregating populations of brinjal.

\section{Materials and Methods}

Present studies were conducted at the Vegetable Research Farm of Department of Vegetable Science and Floriculture, CSKHPKV, Palampur (H.P) during Kharif season 2012 and 2013. The experimental material was developed by using contrasting parents viz; Arka Keshav x Bhola Nath. The varieties possess resistance to bacterial wilt. While selecting the parents' emphasis was given upon the growth habit, fruit shape, fruit colour, fruit maturity, average fruit yield and reaction to bacterial wilt disease.

\section{Mating design}

Experimental material comprising of parents $\left(\mathrm{P}_{1}, \mathrm{P}_{2}\right), \mathrm{F}_{1}, \mathrm{~F}_{2}, \mathrm{BIP}$ 's and $\mathrm{F}_{3}$ generations. Biparental progenies has been developed in $\mathrm{F}_{2}$ generations of an intervarietal crosses using North Carolina Design I as suggested by Comstock and Robinson (1948 and 1952). The biparental progenies (BIP's) and $\mathrm{F}_{3}$ progenies were raised in Randomized Block 
Design (RBD) with three replications. Each experimental plot consisted of two rows of $2.70 \mathrm{~m}$ length for biparental and $F_{3}$ progenies with inter and intra plant distance of $60 \mathrm{~cm}$ and $45 \mathrm{~cm}$, respectively. In addition, six rows of each $\mathrm{F}_{2}$, two rows each of the original parents and $\mathrm{F}_{1}$ 's were also included in each replication for making comparisons. The $\mathrm{F}_{2}$ seeds obtained from crosses attempted during Kharif 2011 were grown during March, 2012. This material was used to produce seeds of biparental and $F_{3}$ progenies. The seeds of $F_{1}$ were also obtained by making fresh crosses. The final experiment was conducted during Kharif 2013.

The observations were recorded on randomly taken five competitive plants in each entry for most of the traits. The characters studied were as follows: days to $50 \%$ flowering, days to first picking, number of marketable fruits per plant, fruit length, fruit diameter, average fruit diameter, plant height, number of branches per plant, fruit weight, pedicel length, total soluble solid, bacterial wilt incidence, dry matter content, iron content, phenol content, marketable yield per plant

The mean over three replications has been subjected to statistical analysis. The method of analysis of variance followed was as proposed by Comstock and Robinson (1948 and 1952). Estimates of correlation coefficient were determined by path analysis given by Dewey and Lu.

\section{Results and Discussion}

Perusal of data in tables 1 and 2 indicated that genotypic correlations in general were higher as compared to their phenotypic correlations indicated strong inherent association between the characters. In case of BIP's, marketable fruit yield per plant showed significant and positive correlation with number of marketable fruits per plant, plant height and fruit weight whereas it was negatively and significantly associated with bacterial wilt incidence. Chattopadhyay et al., (2011), Karak et al., (2012), Nayak and Nagre (2013) and Lakshmi et al., (2014) have also recorded similar results in brinjal. Among the component characters, days to $50 \%$ flowering had positive and significant association days to first picking, fruits per plant, whereas it was negatively correlated with bacterial wilt incidence. Number of marketable fruits per plant had a positive and significant association with plant height and number of branches per plant and non-significantly negative correlation with bacterial wilt incidence. Fruit length showed no significant correlation with any other character in cross $\mathrm{AK} \times \mathrm{BN}$. The fruit diameter was positively correlated with fruit weight and manifested negative and significant association with total soluble solids. The average fruit diameter was positively correlated with fruit weight and negatively and significantly correlated with dry matter content. Plant height was positively and significantly correlated with fruit weight, while it manifested negative correlation with branches per plant.

The fruit weight was positively and significantly correlated with total soluble solids, while it manifested positive correlation with dry matter content in cross $\mathrm{AK} \times \mathrm{BN}$. The fruit weight also exhibited nonsignificant and negative correlations with bacterial wilt incidence.

In $\mathrm{F}_{3}$ progenies, marketable fruit yield per plant was significantly and positively correlated with number of marketable fruits per plant and fruit weight, whereas it was negatively and significantly associated with days to $50 \%$ flowering and bacterial wilt incidence. Among the component characters, days to $50 \%$ flowering manifested positive association with days to first picking, number of marketable fruits per plant, whereas, it was negatively correlated with bacterial wilt incidence. 
Table.1 Estimate of phenotypic correlation coefficient (r) between different pairs of characters in eggplant

\begin{tabular}{|c|c|c|c|c|c|c|c|c|c|c|c|c|c|c|c|c|c|}
\hline & & DTFF & DTFP & NFPP & FL & FD & AFD & PH & BPP & FW & PL & TSS & BWI & DM & IC & PC & MYPP \\
\hline \multirow[t]{2}{*}{ DTFF } & BIP's & 1 & $0.775^{*}$ & $0.696^{*}$ & -0.058 & -0.118 & -0.024 & 0.089 & 0.069 & 0.165 & 0.026 & -0.024 & $-0.335^{*}$ & 0.015 & -0.028 & -0.089 & -0.132 \\
\hline & F3's & 1 & $0.336^{*}$ & $0.435^{*}$ & -0.081 & -0.204 & 0.011 & 0.066 & 0.114 & 0.036 & 0.155 & 0.061 & -0.237 & -0.012 & 0.054 & -0.020 & $-0.419^{*}$ \\
\hline \multirow[t]{2}{*}{ DTFP } & BIP's & & 1 & 0.088 & 0.059 & -0.098 & -0.104 & -0.052 & -0.070 & 0.059 & -0.109 & -0.047 & $-0.699 *$ & 0.106 & 0.107 & -0.038 & 0.094 \\
\hline & F3's & & 1 & $0.411^{*}$ & -0.123 & 0.004 & -0.031 & -0.234 & 0.026 & -0.038 & 0.019 & 0.011 & -0.232 & 0.103 & 0.106 & 0.022 & -0.152 \\
\hline \multirow[t]{2}{*}{ NFPP } & BIP's & & & 1 & -0.026 & 0.091 & 0.135 & 0.163 & 0.044 & $0.798 *$ & 0.142 & 0.099 & $-0.389^{*}$ & -0.016 & -0.069 & -0.029 & $0.794 *$ \\
\hline & F3's & & & 1 & -0.092 & -0.078 & 0.033 & $0.572 *$ & 0.058 & 0.279 & 0.022 & 0.063 & $-0.694^{*}$ & -0.045 & 0.035 & -0.004 & 0.658 \\
\hline \multirow[t]{2}{*}{ FL } & BIP's & & & & 1 & -0.069 & 0.032 & 0.291 & 0.008 & 0.133 & 0.099 & 0.146 & -0.147 & 0.136 & 0.056 & -0.009 & 0.199 \\
\hline & F3's & & & & 1 & 0.125 & 0.014 & $0.483^{*}$ & -0.045 & $0.563 *$ & 0.042 & 0.115 & -0.128 & 0.087 & 0.045 & 0.035 & 0.146 \\
\hline \multirow[t]{2}{*}{ FD } & BIP's & & & & & 1 & $0.794 *$ & 0.047 & 0.155 & $0.475^{*}$ & 0.110 & $-0.314^{*}$ & -0.170 & -0.138 & -0.127 & 0.149 & 0.256 \\
\hline & F3's & & & & & 1 & $0.982 *$ & 0.075 & 0.117 & $0.737 *$ & 0.152 & -0.049 & -0.059 & -0.150 & -0.131 & 0.083 & 0.123 \\
\hline \multirow[t]{2}{*}{ AFD } & BIP's & & & & & & 1 & -0.114 & 0.107 & $0.533^{*}$ & 0.032 & $-0.674^{*}$ & -0.224 & -0.190 & 0.162 & 0.211 & 0.157 \\
\hline & F3's & & & & & & 1 & 0.066 & 0.122 & 0.142 & 0.116 & $-0.335^{*}$ & -0.048 & -0.160 & 0.095 & 0.158 & 0.122 \\
\hline \multirow[t]{2}{*}{$\mathbf{P H}$} & BIP's & & & & & & & 1 & $-0.564 *$ & $0.659 *$ & 0.079 & -0.150 & -0.107 & 0.023 & 0.115 & 0.156 & $0.662 *$ \\
\hline & F3's & & & & & & & 1 & -0.107 & $0.372 *$ & -0.149 & 0.011 & -0.091 & 0.025 & 0.049 & 0.040 & $0.629 *$ \\
\hline \multirow[t]{2}{*}{ BPP } & BIP's & & & & & & & & 1 & 0.054 & 0.030 & 0.159 & -0.131 & 0.166 & 0.132 & 0.146 & 0.094 \\
\hline & F3's & & & & & & & & 1 & 0.122 & 0.068 & 0.029 & -0.225 & 0.110 & 0.043 & 0.079 & 0.253 \\
\hline \multirow[t]{2}{*}{ FW } & BIP's & & & & & & & & & 1 & 0.027 & $0.455^{*}$ & -0.120 & $0.383^{*}$ & 0.007 & 0.121 & $0.881 *$ \\
\hline & F3's & & & & & & & & & 1 & 0.072 & $0.346^{*}$ & -0.014 & $0.445^{*}$ & 0.092 & 0.020 & $0.725^{*}$ \\
\hline \multirow[t]{2}{*}{ PL } & BIP's & & & & & & & & & & 1 & -0.054 & -0.127 & -0.063 & -0.028 & -0.019 & -0.007 \\
\hline & F3's & & & & & & & & & & 1 & 0.171 & -0.172 & 0.163 & 0.155 & 0.086 & 0.216 \\
\hline \multirow[t]{2}{*}{ TSS } & BIP's & & & & & & & & & & & 1 & 0.123 & -0.009 & 0.069 & -0.046 & -0.088 \\
\hline & F3's & & & & & & & & & & & 1 & -0.100 & 0.193 & 0.159 & -0.065 & 0.107 \\
\hline \multirow[t]{2}{*}{ BWI } & BIP's & & & & & & & & & & & & 1 & -0.090 & -0.066 & -0.204 & $-0.495^{*}$ \\
\hline & F3's & & & & & & & & & & & & 1 & -0.083 & -0.048 & -0.165 & $-0.503^{*}$ \\
\hline \multirow[t]{2}{*}{ DM } & BIP's & & & & & & & & & & & & & 1 & 0.153 & -0.113 & 0.201 \\
\hline & F3's & & & & & & & & & & & & & 1 & 0.204 & -0.199 & 0.178 \\
\hline \multirow[t]{2}{*}{ IC } & BIP's & & & & & & & & & & & & & & 1 & 0.045 & 0.209 \\
\hline & F3's & & & & & & & & & & & & & & 1 & 0.153 & -0.133 \\
\hline \multirow[t]{2}{*}{ PC } & BIP's & & & & & & & & & & & & & & & 1 & -0.031 \\
\hline & F3's & & & & & & & & & & & & & & & 1 & -0.196 \\
\hline
\end{tabular}

$\mathrm{DTFF}=$ Days to $50 \%$ flowering, DTFP $=$ Days to first picking, NFPP $=$ Number of marketable fruits per plant, FL $=$ Fruit length, FD $=$ Fruit diameter, AFD = Average fruit diameter, $\mathrm{PH}=$ Plant height, NBPP $=$ Number of branches per plant, $\mathrm{FW}=$ Fruit weight, $\mathrm{PL}=\mathrm{Pedicel}$ length, TSS $=$ Total soluble solid, BWI= Bacterial wilt incidence, $\mathrm{DMC}=$ Dry matter content, $\mathrm{IC}=$ Iron content, $\mathrm{PC}=$ Phenol content, $\mathrm{MYPP}=\mathrm{Marketable}$ yield per plant 
Table.2 Estimate of genotypic correlation coefficient (r) between different pairs of characters in eggplant

\begin{tabular}{|c|c|c|c|c|c|c|c|c|c|c|c|c|c|c|c|c|c|}
\hline & & DTFF & DTFP & NFPP & FL & FD & AFD & $\mathrm{PH}$ & BPP & FW & PL & TSS & BWI & DM & IC & $\mathrm{PC}$ & MYPP \\
\hline \multirow[t]{2}{*}{ DTFF } & BIP's & 1 & $0.812^{*}$ & $0.711 *$ & -0.111 & -0.181 & -0.011 & 0.067 & 0.039 & 0.291 & 0.079 & -0.049 & $-0.451^{*}$ & 0.077 & -0.059 & -0.076 & -0.232 \\
\hline & $\mathrm{F}_{3}{ }^{\prime} \mathrm{s}$ & 1 & $0.621^{*}$ & $0.502 *$ & -0.093 & -0.346 & 0.037 & 0.092 & 0.099 & 0.104 & 0.111 & 0.055 & -0.332 & -0.052 & 0.112 & -0.032 & $-0.355^{*}$ \\
\hline \multirow[t]{2}{*}{ DTFP } & BIP's & & 1 & 0.078 & 0.087 & -0.165 & -0.161 & -0.085 & -0.065 & 0.072 & -0.094 & -0.053 & $-0.568^{*}$ & 0.211 & 0.187 & -0.065 & -0.452 \\
\hline & $\mathrm{F}_{3}{ }^{\prime} \mathrm{s}$ & & 1 & $0.452 *$ & -0.135 & 0.105 & -0.066 & -0.312 & 0.056 & -0.045 & 0.032 & 0.018 & -0.243 & 0.301 & 0.138 & 0.054 & -0.122 \\
\hline \multirow[t]{2}{*}{ NFPP } & BIP's & & & 1 & -0.077 & 0.104 & 0.143 & 0.217 & 0.076 & $0.786^{*}$ & 0.189 & 0.108 & $-0.422^{*}$ & -0.032 & -0.071 & -0.038 & $0.855^{*}$ \\
\hline & $\mathrm{F}_{3}{ }^{\prime} \mathrm{s}$ & & & 1 & -0.113 & -0.115 & 0.089 & $0.602 *$ & 0.061 & 0.456 & 0.035 & 0.075 & $-0.702^{*}$ & -0.057 & 0.054 & -0.014 & $0.764^{*}$ \\
\hline \multirow[t]{2}{*}{ FL } & BIP's & & & & 1 & -0.084 & 0.045 & 0.322 & 0.019 & 0.185 & 0.087 & 0.176 & -0.206 & 0.186 & 0.091 & -0.048 & 0.284 \\
\hline & $\mathrm{F}_{3} \mathrm{~s}^{\prime}$ & & & & 1 & 0.134 & 0.024 & $0.503 *$ & -0.052 & $0.542^{*}$ & 0.034 & 0.133 & -0.144 & 0.092 & 0.082 & 0.055 & 0.413 \\
\hline \multirow[t]{2}{*}{ FD } & BIP's & & & & & 1 & $0.812^{*}$ & 0.092 & 0.162 & $0.533^{*}$ & 0.122 & $-0.452^{*}$ & -0.154 & -0.129 & -0.131 & 0.153 & 0.532 \\
\hline & $\mathrm{F}_{3}{ }^{\prime} \mathrm{s}$ & & & & & 1 & $0.879 *$ & 0.075 & 0.159 & $0.795^{*}$ & 0.174 & -0.083 & -0.035 & -0.165 & -0.154 & 0.093 & 0.611 \\
\hline \multirow[t]{2}{*}{ AFD } & BIP's & & & & & & 1 & -0.132 & 0.128 & $0.621 *$ & 0.094 & $-0.712 *$ & -0.325 & -0.217 & 0.187 & 0.273 & 0.515 \\
\hline & $\mathrm{F}_{3}{ }^{\prime} \mathrm{s}$ & & & & & & 1 & 0.053 & 0.135 & 0.182 & 0.123 & $-0.451 *$ & -0.079 & -0.233 & 0.105 & 0.193 & 0.646 \\
\hline \multirow[t]{2}{*}{$\mathrm{PH}$} & BIP's & & & & & & & 1 & $-0.628^{*}$ & $0.643^{*}$ & 0.104 & -0.213 & -0.142 & 0.073 & 0.171 & 0.182 & $0.753^{*}$ \\
\hline & $\mathrm{F}_{3} \mathrm{~s}^{\prime}$ & & & & & & & 1 & -0.118 & $0.442 *$ & -0.185 & 0.078 & -0.111 & 0.049 & 0.059 & 0.104 & $0.686^{*}$ \\
\hline \multirow[t]{2}{*}{ BPP } & BIP's & & & & & & & & 1 & 0.089 & 0.067 & 0.174 & -0.145 & 0.210 & 0.162 & 0.189 & 0.254 \\
\hline & $\mathrm{F}_{3}{ }^{\prime} \mathrm{s}$ & & & & & & & & 1 & 0.213 & 0.106 & 0.045 & -0.284 & 0.095 & 0.113 & 0.049 & 0.182 \\
\hline \multirow[t]{2}{*}{ FW } & BIP's & & & & & & & & & 1 & 0.086 & $0.524^{*}$ & -0.167 & $0.427 *$ & 0.018 & 0.234 & $0.982^{*}$ \\
\hline & $\mathrm{F}_{3}{ }^{\prime} \mathrm{s}$ & & & & & & & & & 1 & 0.092 & $0.483^{*}$ & -0.045 & $0.496^{*}$ & 0.045 & 0.187 & $0.802 *$ \\
\hline \multirow[t]{2}{*}{ PL } & BIP's & & & & & & & & & & 1 & -0.056 & -0.189 & -0.063 & -0.053 & -0.044 & -0.312 \\
\hline & $\mathrm{F}_{3}{ }^{\prime} \mathrm{s}$ & & & & & & & & & & 1 & 0.086 & -0.173 & 0.163 & 0.176 & 0.102 & 0.298 \\
\hline \multirow[t]{2}{*}{ TSS } & BIP's & & & & & & & & & & & 1 & 0.132 & -0.031 & 0.056 & -0.082 & 0.422 \\
\hline & $\mathrm{F}_{3}{ }^{\prime} \mathrm{s}$ & & & & & & & & & & & 1 & -0.064 & 0.045 & 0.174 & -0.078 & 0.346 \\
\hline \multirow[t]{2}{*}{ BWI } & BIP's & & & & & & & & & & & & 1 & -0.103 & -0.015 & -0.155 & $-0.433^{*}$ \\
\hline & $\mathrm{F}_{3} \mathrm{~s}^{\prime}$ & & & & & & & & & & & & 1 & -0.068 & -0.054 & -0.099 & $-0.335^{*}$ \\
\hline \multirow[t]{2}{*}{$\mathrm{DM}$} & BIP's & & & & & & & & & & & & & 1 & 0.167 & -0.156 & 0.412 \\
\hline & $\mathrm{F}_{3}{ }^{\prime} \mathrm{s}$ & & & & & & & & & & & & & 1 & 0.134 & -0.165 & 0.257 \\
\hline \multirow[t]{2}{*}{ IC } & BIP's & & & & & & & & & & & & & & 1 & 0.078 & 0.165 \\
\hline & $\mathrm{F}_{3}{ }^{\prime} \mathrm{s}$ & & & & & & & & & & & & & & 1 & 0.217 & 0.234 \\
\hline \multirow[t]{2}{*}{ PC } & BIP's & & & & & & & & & & & & & & & 1 & -0.412 \\
\hline & $\mathrm{F}_{3}^{\prime} \mathrm{s}$ & & & & & & & & & & & & & & & 1 & -0.288 \\
\hline
\end{tabular}

$\mathrm{DTFF}=$ Days to $50 \%$ flowering, DTFP $=$ Days to first picking, NFPP $=$ Number of marketable fruits per plant, FL $=$ Fruit length, FD $=$ Fruit diameter, AFD = Average fruit diameter, $\mathrm{PH}=$ Plant height, $\mathrm{NBPP}=$ Number of branches per plant, $\mathrm{FW}=$ Fruit weight, $\mathrm{PL}=$ Pedicel length, $\mathrm{TSS}=$ Total soluble solid, $\mathrm{BWI}=$ Bacterial wilt incidence, $\mathrm{DMC}=$ Dry matter content, $\mathrm{IC}=$ Iron content, $\mathrm{PC}=\mathrm{Phenol}$ content, $\mathrm{MYPP}=$ Marketable yield per plant 
Table.3 Estimates of direct and indirect effects at the phenotypic level in biparental progenies of cross Arka Keshav X Bhola Nath (AK x BN)

\begin{tabular}{|c|c|c|c|c|c|c|c|c|c|c|c|c|c|c|c|}
\hline & DTFF & DTFP & NFPP & FL & FD & AFD & $\mathbf{P H}$ & BPP & FW & PL & TSS & BWI & DM & IC & PC \\
\hline DTFF & -0.051 & 0.041 & -0.030 & 0.009 & 0.015 & 0.012 & -0.030 & 0.019 & 0.034 & 0.001 & 0.001 & -0.017 & 0.011 & 0.006 & 0.009 \\
\hline DTFP & -0.042 & 0.053 & -0.029 & -0.028 & 0.011 & -0.009 & 0.028 & 0.019 & -0.031 & 0.006 & -0.003 & 0.016 & -0.005 & -0.065 & -0.012 \\
\hline NFPP & -0.175 & 0.097 & 0.330 & -0.022 & 0.012 & 0.013 & 0.121 & 0.013 & 0.249 & -0.034 & 0.003 & 0.011 & -0.006 & -0.048 & -0.009 \\
\hline FL & 0.078 & 0.073 & 0.182 & 0.290 & 0.066 & 0.075 & 0.083 & 0.057 & 0.075 & 0.001 & 0.020 & -0.035 & 0.033 & 0.036 & 0.013 \\
\hline FD & 0.071 & -0.049 & 0.076 & 0.015 & 0.245 & 0.095 & 0.109 & 0.018 & 0.052 & 0.012 & 0.042 & -0.028 & 0.058 & 0.031 & 0.017 \\
\hline AFD & 0.003 & -0.060 & 0.012 & -0.073 & -0.179 & 0.126 & 0.015 & -0.067 & 0.075 & 0.006 & -0.137 & 0.073 & -0.092 & -0.052 & -0.018 \\
\hline $\mathbf{P H}$ & 0.053 & 0.048 & 0.097 & 0.103 & 0.116 & 0.107 & 0.309 & 0.094 & 0.192 & 0.002 & 0.013 & -0.105 & 0.084 & 0.056 & 0.005 \\
\hline BPP & 0.023 & 0.023 & 0.027 & 0.026 & 0.009 & 0.013 & -0.013 & 0.063 & 0.022 & 0.002 & 0.010 & -0.008 & -0.016 & 0.008 & 0.009 \\
\hline FW & -0.114 & 0.092 & 0.148 & 0.112 & 0.036 & 0.039 & 0.103 & 0.060 & 0.471 & 0.005 & 0.009 & -0.054 & 0.031 & 0.035 & 0.014 \\
\hline PL & 0.001 & -0.044 & -0.004 & 0.003 & 0.006 & -0.007 & -0.002 & -0.001 & -0.001 & $|-0.029|$ & 0.002 & 0.004 & -0.002 & 0.001 & -0.001 \\
\hline TSS & -0.003 & -0.025 & -0.010 & -0.015 & -0.003 & -0.002 & 0.005 & 0.007 & 0.006 & 0.006 & 0.075 & -0.000 & -0.021 & -0.007 & -0.005 \\
\hline BWI & 0.000 & 0.058 & 0.002 & -0.001 & -0.002 & -0.004 & -0.001 & 0.005 & 0.002 & 0.002 & -0.001 & -0.194 & -0.017 & -0.013 & -0.007 \\
\hline DM & 0.000 & 0.015 & 0.000 & 0.003 & 0.003 & 0.007 & 0.003 & 0.003 & 0.006 & 0.008 & 0.001 & -0.013 & 0.140 & 0.022 & -0.016 \\
\hline IC & 0.005 & -0.013 & 0.001 & 0.002 & 0.002 & 0.000 & 0.001 & 0.001 & 0.006 & 0.003 & 0.009 & -0.008 & 0.019 & 0.126 & 0.006 \\
\hline PC & 0.002 & 0.002 & 0.003 & -0.003 & -0.003 & -0.003 & 0.004 & 0.001 & -0.003 & 0.000 & -0.001 & -0.005 & 0.201 & 0.209 & -0.019 \\
\hline Coeff. of corr. with MYPP & -0.132 & 0.094 & 0.794* & 0.199 & 0.256 & 0.157 & $0.662 *$ & 0.094 & $0.881 *$ & -0.007 & -0.088 & $-0.495 *$ & 0.201 & 0.209 & -0.031 \\
\hline
\end{tabular}

Residual effect: 0.0053 (Underlined values denotes direct effects and the remaining indirect effects) 
Number of marketable fruits per plant was positively and significantly associated with plant height, fruit weight, whereas it was negatively correlated with bacterial wilt incidence. Fruit length was significantly and positively correlated with plant height and fruit weight and negative and non-significant association was observed with number of branches per plant. The fruit diameter was positively correlated with average fruit diameter and fruit weight. The average fruit diameter was positively correlated with fruit weight and negatively and significantly correlated with dry matter content. Positive and significant correlation of plant height with fruit weight was observed. The fruit weight was positively and significantly correlated with total soluble solids and dry matter content in cross $\mathrm{AK} \times \mathrm{BN}$. The fruit weight also exhibited non-significant and negative correlations with bacterial wilt incidence

Total association between a pair of characters is measured by the correlation coefficients. But the association between the two characters comprises of a complicated pathway involving various other attributes, which may have direct or indirect effects on the dependent characters. Direct contribution of the component characters to fruit weight and the indirect effects, which there may have through their relationship with each other been isolated out through path analysis (Table 3).

While comparing the BIP's and F3 families with respect to the direct effects of the component characters, it was observed that best expression of the effect in respect of fruit weight was obtained in BIP's and F3 progenies of both the crosses. A perusal of the indirect effect of various component characters on marketable fruit yield indicated that fruit weight via number of marketable fruits per plant, fruit length and plant height contributed the maximum in biparental and F3 progenies. Fruit weight had the highest direct effects in the BIP's and F3 progenies. Number of marketable fruits per plant, as well as plant height also contributed substantially indirectly through fruit weight for BIP's and F3 progenies. From the above results, it appeared that inter-mating influenced both direct and indirect effects of various characters on fruit yield. Similar observations have also been recorded by Nair and Mehta (2008), Tripathi et al., (2009) and Kumar et al., (2013) in brinjal.

Nayak and Nagre (2013) revealed that fruit length, diameter and weight influenced the fruit yield with high direct effect and significant positive correlation. Therefore, fruit length, diameter and weight are important characters which may be included in selection criteria for improvement in fruit yield per plant. Lakshmi et al., (2014) revealed positive and highly significant association of number of flowers per cluster, number of fruits per cluster, average fruit length and number of fruits per plant with fruit yield in brinjal. Path coefficient analysis revealed that the characters viz., fruit set percentage, fruit weight, number of fruits per plant, relative style length, number of flowers per cluster and number of fruits per cluster had high direct effect and correlation values. Thus, the fruit yield per plant can be improved by making selection of these characters during yield improvement programme.

In conclusion, the association studies revealed that marketable fruit yield was positively and significantly correlated with fruits per plant, plant height and fruit weight in BIP's and $\mathrm{F}_{3}$ progenies. The four quality attributes viz., dry matter, total soluble solids, iron content and phenol content appeared to be independent of each other as correlation among them were found to be non-significant. Path analysis indicated that fruit weight had a maximum direct effect with marketable fruit yield. Indirect effects of fruit weight on marketable fruit yield via other characters viz., number of marketable fruits per plant, plant height and fruit length were also of higher magnitude. Thus, predicting the true relationship of fruit weight with marketable fruit yield. As such, selection based on fruit weight would prove fruitful and rewarding for obtaining high fruit yield. 


\section{Acknowledgement}

The authors gratefully acknowledge Department of Science and Technology, Govt. of India for providing financial assistance during the period of research.

\section{References}

Zeven, A.C. and Zhukovsky, P.M. 1975. Dictionary of cultivated plants and their centers of diversity. Wageningen, Netherlands. p 219.

Hazra, P., A. Chattopadhyay, K. Karmakar and Dutta, S. 2011. Brinjal In: Modern Technology in Vegetable Production. New India Publishing Agency, New Delhi. pp. 103 - 114.

Adams, M.W. and Grafius, J.E. 1971. Yield components compensation: alternative interpretation. Crop Science 11: 33-35.

Nath, P., Velayudhan, S. and Singh, D.P. 1987. Vegetable for the Tropical Region. Indian Council of Agricultural Research, New Delhi, pp 23-24.

Comstock, R.E. and Robinson, H.F.1948. The component of genetic variance in populations of biparental progenies and their use in estimating the average degree of dominance. Biometrics 4: 254-266.

Comstock, R.E. and Robinson, H.F.1952. Estimation of average dominance of genes. In: Heterosis. IOWA State College Press, Ames. Iowa. pp 494-516.

Naik, V.R., M.G. Bentur and Parameshwarappa, K.G. 2009. Impact of biparental mating on genetic variability and path analysis in safflower. Karnataka Journal of Agricultural Sciences 22(1): 44-46.

Nainar, P., R. Subbiah and Irulappan, I.1991. Variability, heritability and genetic advance in brinjal. South Indian horticulture 39(1): 32-36.
Naliyadhara, M.V., I.J. Golani, D.R. Mehta and Purohit, V.L. 2007. Genetic variability, correlation co-efficient and path analysis in brinjal. Orissa Journal of Horticulture 35(2): 92-96.

Dharwad, N.A., P.M. Salimath and Patil, S.A. 2009. Association and path co-efficient analysis in elite germplasm lines of brinjal (Solanum Melongena L.). Karnataka Journal of Agricultural Sciences 22 (5).

Lakshmi, R.R., S.S. Vijaya, L. Padma, N. Naidu and Umajyothi, K. 2014. Correlation and path analysis studies of yield and yield components in brinjal. Plant Archives 14 (1): 583-591.

Chattopadhyay, A., S Dutta and Hazra P. 2011. Characterization of genetic resources and identification of selection indices of brinjal (Solanum melongena L.) grown in Eastern India. Vegetable Crops Research Bulletin 74: 39-49.

Saraswathi, T. and Shivashankar, K.T.1998. Gene action for bacterial wilt resistance in brinjal (Solanum melongena) crosses. South Indian Horticulture 46(1/2): 106-108.

Deepalakshmi, C.N., Y.A. Vasline, P. Panneerselvam and Ganesan, J. 2004. Correlation studies in $F_{2}, F_{3}$ and BIP populations of sesame (Sesamum indicum L.). Sesame and Safflower Newsletter (19)

Kanwar, M.S. and Korla, B.N. 2002. Performance of biparental progenies in late cauliflower: variability and association analysis. Vegetable Science 29(1): 13-16.

Sharma, A. and Kalia, P. 2003. Studies on biparental progenies in garden pea (Pisum sativum L.). Indian Journal of Genetics and Plant Breeding 63 (1): 79-80.

Rajput, J.C., S.S. Pandit, S.S. Patil and Patil, V.H.1996. Variability, heritability and inter-relationship of important quantitative characters in Brinjal. Annals Agric. Res. 17: 235-240.

\section{How to cite this article:}

Aanchal Chauhan, K.S. Chandel and Shiv Pratap. 2017. Correlation Studies in Segregating Population of Brinjal (Solanum melongena L.) Developed Through Bi-Parental Mating Using Bacterial Wilt Resistant Varieties. Int.J.Curr.Microbiol.App.Sci. 6(8): 1936-1943.

doi: https://doi.org/10.20546/ijcmas.2017.608.229 